\title{
Treatment of oil-containing wastewater of machine-building enterprises using pressure hydrocyclones
}

\author{
Andrey Busarev*1[0000-0002-7063-2519], and Aleksandr Selyugin 10000-0003-2427-3698] \\ ${ }^{1}$ Kazan State University of Architecture and Engineering, 420043 Kazan, Russia
}

\begin{abstract}
Wastewater treatment of machine-building enterprises contaminated with oils, petroleum products and mechanical impurities is an urgent task. A promising direction in the field of treatment of such wastewater is the use of pressure hydrocyclones and hydrocyclone installations. The article presents the results of research on the treatment of oil-containing wastewater of machine-building enterprises in pressure of hydrocyclones, conducted on an experimental hydrocyclone installation, which includes the pressure hydrocyclone under test, a sedative tank, and tanks for receiving water from the upper and lower drains of the hydrocyclone. The studies were carried out in two stages: the first stage was used to determine the diameter of the pressure of hydrocyclone suitable for the treatment of oily wastewater, and the second stage was used to study its geometric characteristics. At the first stage, seven modifications of pressure hydrocyclones with a diameter of 40 to $100 \mathrm{~mm}$ with different diameters of the upper and lower drain pipes were tested. A $75 \mathrm{~mm}$ diameter hydrocyclone is recommended for the treatment of oily wastewater. At the second stage, nine pressure hydrocyclones with a diameter of $75 \mathrm{~mm}$ with different diameters of the upper and lower drain pipes were tested. As a result of the experiments, the design parameters of the hydrocyclone that showed the best results were determined. The results of the research were used in the design of industrial hydrocyclone installations.
\end{abstract}

Keywords. Oily wastewater, treatment, hydrocyclone, experimental plant, research, industrial plant.

\section{Introduction}

Oil-containing waste water is formed in oil fields during the production and preparation of oil, during car washing, from the cooling of technological equipment at machine-building enterprises, in fuel oil storage tanks, etc.

For the treatment of wastewater from petroleum products and suspended solids, settling tanks of various designs are often used [1-4]. Hydrocyclones with different geometries are often used for the treatment of oily wastewater [5-9].

Kazan State University of Architecture and Engineering (KSUAE) has developed devices that combine the treatment of oil-containing wastewater in pressure hydrocyclones,

*Corresponding author: kgasu.viv@gmail.com 
succeeded by purification from petroleum products and suspended substances by sedimentation. These installations are called the «hydrocyclone - sump block» (HSB) $[10,11]$. Coalescing nozzles made of granular materials are used to intensify the deposition of oily wastewater [12].

Chemical purification of water from petroleum products is carried out by the method of oxidation [13-16]. Biological purification of water from petroleum products is carried out using membrane bioreactors [17-20].

Physical and chemical methods are also used for the treatment of oily wastewater: flotation [21], sorption [22], ultrafiltration [23], as well as electrocoagulation [24].

Deep purification of oil-containing wastewater from petroleum products and suspended substances is carried out in filters with granular loading [25-27].

The aim of the study was to define the geometric parameters of the pressure hydrocyclone for its use in industrial hydrocyclone facilities for the treatment of oil-containing waste water effluent.

\section{Materials and methods}

Studies of the oil-containing wastewater treatment processes at machine-building enterprises were carried out in two stages: at the first stage, the diameter of the pressure hydro cyclone was determined, and at the second stage, its geometric characteristics were determined. At the first stage, seven modifications of pressure hydrocyclones with a diameter of 40 to 100 $\mathrm{mm}$ with different diameters of the upper and lower drain pipes were tested.

To determine the geometric parameters of the hydrocyclone intended for operation as part of the installation of the «hydrocyclone - sump unit», studies of the oil-containing wastewater treatment processes were carried out on an experimental hydrocyclone installation (Fig. 1).

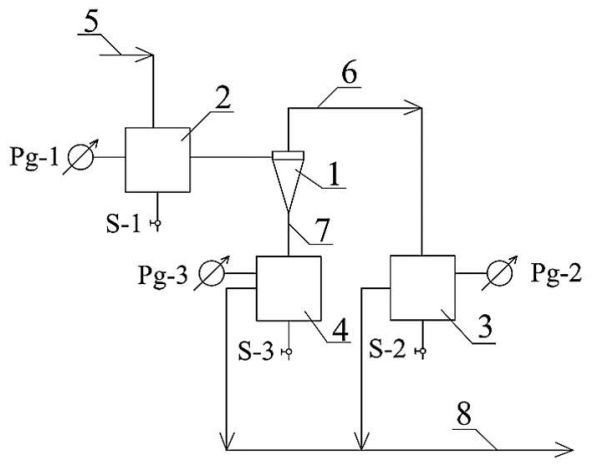

Fig. 1. The Scheme of the experimental installation: 1 - pressure hydrocyclone; 2 - sedative tank; 3 - tank for receiving water from the upper drain of the hydrocyclone; 4 - tank for receiving water from the lower drain of the hydrocyclone; 5 - waste water supply; 6 - pipeline of the upper drain of the hydrocyclone; 7 - pipeline of the lower drain of the hydrocyclone; 8 - pipeline for removing liquid to the sewer.

During the research, oil-containing waste water was supplied to the installation by a pump through pipeline 5 . Water from the upper drain of the hydrocyclones was diverted through pipeline 6 , and from the lower drain of these devices - through pipeline 7. From tanks 3 and 4 , the liquid was diverted through pipeline 8 to the industrial sewage system. The pressure at the inlet to the hydrocyclones was set according to the readings of the pressure gauge Pg-1 installed on the tank 2 .

In the course of the research, after the flows at the inlet to the hydrocyclone and at its drains became steady, samples of the initial waste water from the S-1 sampler and liquid from the upper and lower drains of the hydrocyclone from the Pg-2 and Pg-3 samplers were simultaneously taken. In the samples, the concentration of mechanical impurities was 
determined by the weight method, and the concentration of petroleum products was determined by the photo colorimetric method $[1,28]$.

Table 1 shows the geometric characteristics of the hydrocyclones tested in the course of experimental studies.

Table 1. Geometric characteristics of hydrocyclones with a diameter of 40-100 $\mathrm{mm}$.

\begin{tabular}{|c|c|c|c|c|c|c|c|}
\hline \multirow{2}{*}{$\begin{array}{l}\text { Type of } \\
\text { the hydro- } \\
\text { cyclone }\end{array}$} & \multicolumn{4}{|c|}{ Diameter, mm } & \multirow{2}{*}{$\begin{array}{l}\text { Immersion } \\
\text { dept of the } \\
\text { upper drain } \\
\text { pipe, mm }\end{array}$} & \multirow{2}{*}{$\begin{array}{l}\text { Height of the } \\
\text { cylindrical } \\
\text { part, mm }\end{array}$} & \multirow{2}{*}{$\begin{array}{l}\text { Total height } \\
\text { of the hydro- } \\
\text { cyclone, mm }\end{array}$} \\
\hline & $\begin{array}{l}\text { hydro- } \\
\text { cyclone }\end{array}$ & $\begin{array}{l}\text { Inlet } \\
\text { pipe }\end{array}$ & $\begin{array}{l}\text { upper- } \\
\text { drain } \\
\text { pipe }\end{array}$ & $\begin{array}{c}\text { Lower } \\
\text { drain } \\
\text { pipe }\end{array}$ & & & \\
\hline HC-40-V & 40 & 15 & 15 & 10 & 48 & 15 & 525 \\
\hline HC-40-III & 40 & 15 & 8 & 5 & 20 & 15 & 470 \\
\hline HC-75-II & 75 & 15 & 20 & 18 & 48 & 15 & 730 \\
\hline HC-75-III & 75 & 15 & 20 & 10 & 48 & 15 & 730 \\
\hline HC-80-I & 80 & 20 & 20 & 10 & 50 & 20 & 745 \\
\hline HC-100-I & 100 & 20 & 20 & 15 & 48 & 20 & 1100 \\
\hline HC-100-II & 100 & 20 & 20 & 10 & 48 & 20 & 1155 \\
\hline
\end{tabular}

At the second stage, the research of a $75 \mathrm{~mm}$ diameter hydrocyclone was carried out. In the course of the studies, the diameters of the upper and lower drain pipes were changed. The geometrical characteristics of the tested hydrocyclones are given in Table 2.

Table 2. Geometric characteristics of $75 \mathrm{~mm}$ diameter hydrocyclones.

\begin{tabular}{|c|c|c|c|c|c|c|c|}
\hline $\begin{array}{c}\text { Type of } \\
\text { the hydro- } \\
\text { cyclone }\end{array}$ & \multicolumn{4}{|c|}{ Diameter, mm } & Immersion & hydro- \\
cyclone & $\begin{array}{c}\text { Inlet } \\
\text { pipe }\end{array}$ & $\begin{array}{c}\text { upper- } \\
\text { drain } \\
\text { pipe }\end{array}$ & $\begin{array}{c}\text { Lower } \\
\text { drain } \\
\text { pipe }\end{array}$ & $\begin{array}{c}\text { upper drain } \\
\text { pipe, mm }\end{array}$ & $\begin{array}{c}\text { Height of the } \\
\text { cylindri-cal } \\
\text { part, mm }\end{array}$ & $\begin{array}{c}\text { Total height } \\
\text { of the hydro- } \\
\text { cyclone, mm }\end{array}$ \\
\hline HC-75-I & 75 & 15 & 20 & 26 & 48 & 15 & 730 \\
\hline HC-75-II & 75 & 15 & 20 & 18 & 48 & 15 & 730 \\
\hline HC-75-III & 75 & 15 & 20 & 10 & 48 & 15 & 730 \\
\hline HC-75-IV & 75 & 15 & 15 & 18 & 48 & 15 & 730 \\
\hline HC-75-V & 75 & 15 & 15 & 26 & 48 & 15 & 730 \\
\hline HC-75-VI & 75 & 15 & 15 & 10 & 48 & 15 & 730 \\
\hline HC-75-VII & 75 & 15 & 10 & 18 & 48 & 15 & 730 \\
\hline HC-75-VIII & 75 & 15 & 10 & 10 & 48 & 15 & 730 \\
\hline HC-75-IX & 75 & 15 & 10 & 26 & 48 & 15 & 730 \\
\hline
\end{tabular}

The effect of oil-containing wastewater treatment from petroleum products, $E_{p}, \%$, is determined by the formula [28]:

$$
E_{p . p .}=\frac{C_{p . p .}^{s w .}-C_{p . p .}^{l d}}{C_{p . p .}^{S W .}} \cdot 100, \%
$$

where $\mathrm{C}_{p . p}^{S w}$. - is the concentration of petroleum products in the source water, $m g / l ; \mathrm{C}_{p . p .}^{l d}-$ is the concentration of petroleum products in the water from the lower drain

of the hydrocyclone, $m g / l$.

The effect of purification by mechanical impurities $E_{m . i .}, \%$, was determined by the formula $[23,28]$ :

$$
E_{m . i .}=\frac{c_{m . i}^{s w}-C_{m . i .}^{l d}}{\mathrm{C}_{m . i .}^{s w .}} \cdot 100, \%
$$

where $\mathrm{C}_{m . i .}^{s w}$ is - the concentration of mechanical impurities in the source water, $m g / l ; \mathrm{C}_{m . i .}^{l d}-$ is the concentration of mechanical impurities in the purified water, $m g / l$. 


\section{Results and discussion}

Tables 3a-b show the results of studies on the treatment of oily wastewater in pressure hydrocyclones of various diameters.

Table 3a. Results of experimental studies.

\begin{tabular}{|c|c|c|c|c|c|c|c|}
\hline \multirow{2}{*}{$\begin{array}{l}\text { Type } \\
\text { of } \\
\text { hydro- } \\
\text { cyclone }\end{array}$} & \multirow{2}{*}{$\begin{array}{c}\text { Waste } \\
\text { water } \\
\text { temper } \\
\text { ature, } \\
{ }^{0} \mathrm{C}\end{array}$} & \multirow{2}{*}{$\begin{array}{c}\text { Pressure } \\
\text { at the } \\
\text { inlet to } \\
\text { the } \\
\text { hydrocyc } \\
\text {-lone, } \\
\mathrm{MPa}\end{array}$} & \multirow{2}{*}{$\begin{array}{l}\text { Back } \\
\text { pressure } \\
\text { at the } \\
\text { jet- } \\
\text { cyclone } \\
\text { drains, } \\
\text { MPa }\end{array}$} & \multicolumn{3}{|c|}{$\begin{array}{l}\text { Concentration of petroleum products } \\
\text { in water, } m g / l\end{array}$} & \multirow{2}{*}{$\begin{array}{c}\text { The effect of } \\
\text { cleaning oil } \\
\text { products, } \\
E_{\text {p.p. } \%}\end{array}$} \\
\hline & & & & $\begin{array}{l}\text { In the } \\
\text { sourcew } \\
\text { ater, } \\
C_{p . p .}^{s w}\end{array}$ & $\begin{array}{c}\text { From the } \\
\text { upper } \\
\text { drain, } \\
C_{p . p .}^{u d}\end{array}$ & $\begin{array}{c}\text { From the } \\
\text { lower } \\
\text { drain, } \\
C_{p . p .}^{l d}\end{array}$ & \\
\hline 1 & 2 & 3 & 4 & 5 & 6 & 7 & 8 \\
\hline \multirow{4}{*}{ HC-40-III } & \multirow{4}{*}{18.80} & \multirow{4}{*}{0.3} & 0.05 & 521 & 799 & 162 & 69 \\
\hline & & & 0.10 & 483 & 827 & 140 & 71 \\
\hline & & & 0.15 & 492 & 783 & 157 & 68 \\
\hline & & & 0.20 & 509 & 815 & 173 & 66 \\
\hline \multirow{4}{*}{ HC-40-V } & \multirow{4}{*}{19.2} & \multirow{4}{*}{0.3} & 0.05 & 484 & 784 & 111 & 77 \\
\hline & & & 0.10 & 497 & 749 & 119 & 76 \\
\hline & & & 0.15 & 511 & 785 & 133 & 74 \\
\hline & & & 0.20 & 490 & 691 & 137 & 72 \\
\hline \multirow{4}{*}{ HC-75-II } & \multirow{4}{*}{18.9} & \multirow{4}{*}{0.3} & 0.05 & 504 & 737 & 141 & 72 \\
\hline & & & 0.10 & 490 & 743 & 147 & 70 \\
\hline & & & 0.15 & 488 & 635 & 156 & 68 \\
\hline & & & 0.20 & 493 & 680 & 167 & 66 \\
\hline \multirow{4}{*}{ HC-75- III } & \multirow{4}{*}{19.0} & \multirow{4}{*}{0.3} & 0.05 & 501 & 764 & 159 & 68 \\
\hline & & & 0.10 & 498 & 787 & 174 & 65 \\
\hline & & & 0.15 & 486 & 699 & 190 & 61 \\
\hline & & & 0.20 & 492 & 702 & 207 & 58 \\
\hline \multirow{4}{*}{ HC-80-I } & \multirow{4}{*}{19.1} & \multirow{4}{*}{0.3} & 0.05 & 507 & 699 & 177 & 65 \\
\hline & & & 0.10 & 489 & 673 & 196 & 60 \\
\hline & & & 0.15 & 495 & 698 & 213 & 57 \\
\hline & & & 0.20 & 488 & 701 & 224 & 54 \\
\hline \multirow{4}{*}{ HC-100-I } & \multirow{4}{*}{19.1} & \multirow{4}{*}{0.3} & 0.05 & 499 & 689 & 190 & 62 \\
\hline & & & 0.10 & 482 & 671 & 188 & 61 \\
\hline & & & 0.15 & 522 & 695 & 214 & 59 \\
\hline & & & 0.20 & 491 & 683 & 211 & 57 \\
\hline \multirow{4}{*}{ HC-100-II } & \multirow{4}{*}{18.90} & \multirow{4}{*}{0.3} & 0.05 & 485 & 662 & 175 & 64 \\
\hline & & & 0.10 & 496 & 650 & 173 & 65 \\
\hline & & & 0.15 & 508 & 637 & 188 & 63 \\
\hline & & & 0.20 & 513 & 649 & 307 & 62 \\
\hline
\end{tabular}

During the second stage of the research, the concentration of petroleum products in the wastewater entering the hydrocyclone for treatment was in the range of $442-2937 \mathrm{mg} / \mathrm{l}$, and mechanical impurities $-82-111 \mathrm{mg} / \mathrm{l}$. The results of studies of wastewater treatment in hydrocyclones are shown in Figures 2 and 3. 
Table 3b. Results of experimental studies.

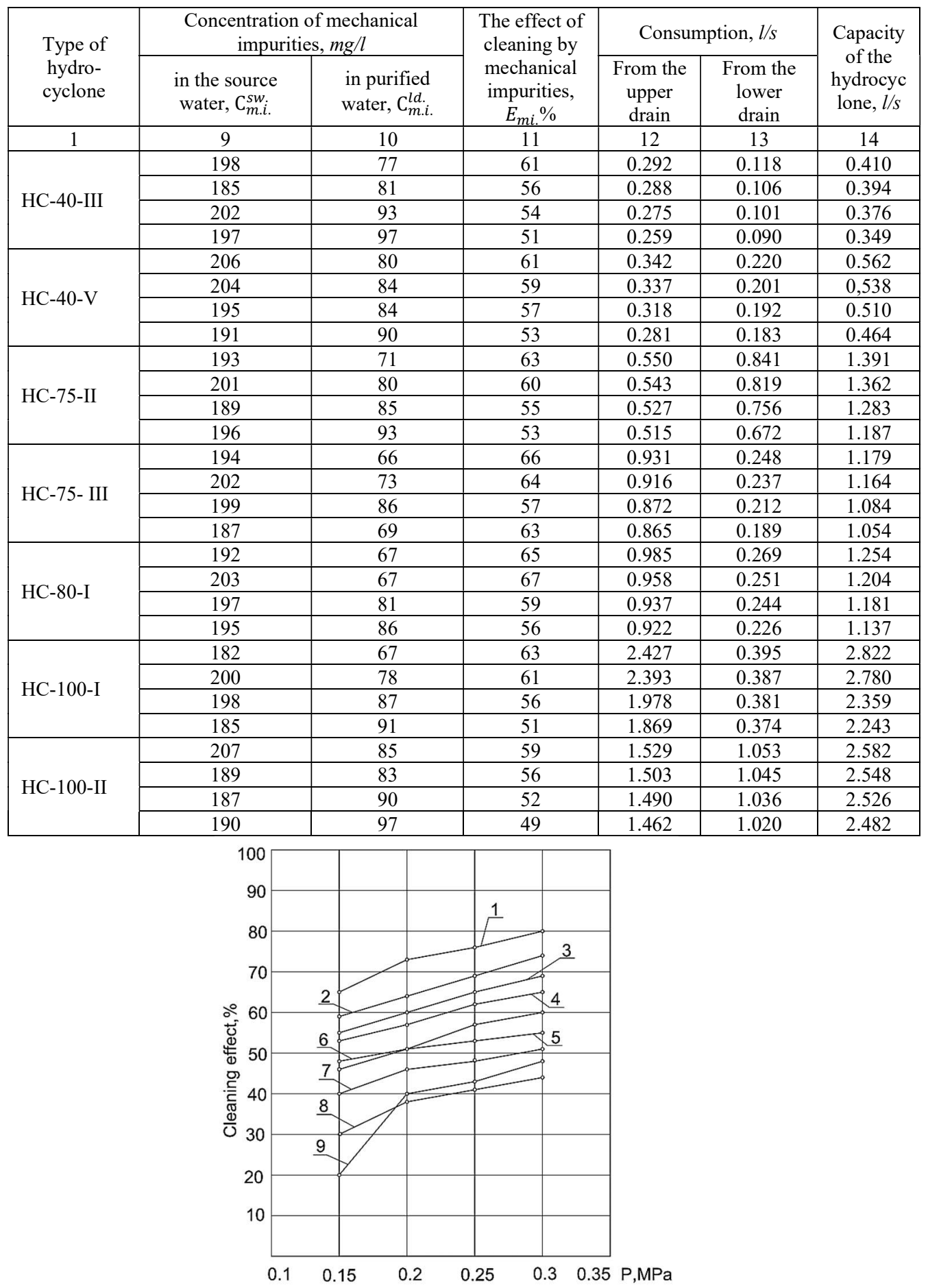

Fig. 2. Dependence of the efficiency of oily wastewater treatment for petroleum products on the pressure at the inlet to the hydrocyclone: 1 - HC-75-II; 2 - HC-75-I; 3 - HC-75-III; 4 - HC-75-VI; 5 - HC-75-VII; 6 - HC-75-VI; 7 - HC-75-VIII; 8 - HC-75-IX; 9 - HC-75-V. 


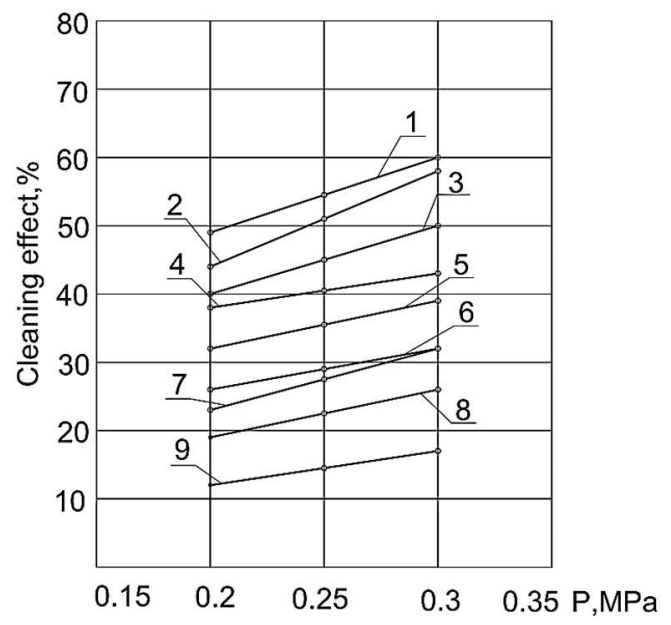

Fig. 3. Dependence of the efficiency of oily wastewater treatment by mechanical impurities on the pressure at the inlet to the hydrocyclone: 1 - HC-75-III; 2 - HC-75-II; 3 - HC-75-I; 4 - HC-75-VI; 5 - HC-75-IV; 6 - HC-75-III; 7 - HC-75-V; 8 - HC-75-VII; 9 - HC-75-IX.

\section{Conclusion}

The conclusions drawn from this study can be summarized in the following statements. Results of the first stage of research.

It is established that hydrocyclones with a diameter of $40 \mathrm{~mm}$ have a high efficiency of cleaning of oily wastewater, but a small capacity, and hydrocyclones with a diameter of 100 $\mathrm{mm}$ have a large capacity, but for their effective operation, a greater pressure at the inlet to the hydrocyclone is required. The pressure hydrocyclone HC-80-I has shown a high efficiency of wastewater treatment from mechanical impurities, but has a low efficiency of wastewater treatment from petroleum products. According to the research results, the pressure hydrocyclone HC-75-II is recommended for the treatment of oily wastewater.

The results of the second stage of research:

a) the efficiency of wastewater treatment for petroleum products was $20-80 \%$, and for mechanical admixtures $12-60 \%$;

b) as the pressure increases, the performance and efficiency of the hydrocyclones increases;

c) for the treatment of oily wastewater, it is recommended to use a hydrocyclone of the HC-75-II type.

According to the results of experimental studies, the possibility of sufficiently effective treatment of oily wastewater from machine-building enterprises in pressure hydrocyclones has been established. The geometric parameters of the pressure hydrocyclone for the treatment of oily wastewater are determined. The experimental data obtained were used in the calculation and design of industrial plants HSB-300 with a capacity of $300 \mathrm{~m}^{3} /$ day and the hydrocyclone installation-sump HIS-150 with a capacity of $150 \mathrm{~m}^{3} /$ day. These installations consist of pressure hydrocyclones HC-75-II and sedimentation tanks of the lower and upper drains, equipped with distribution, collection systems and oil collecting devices.

\section{References}

1. M.I. Farakhov, A.G. Laptev, M.M. Basharov. Theor. Found. Chem. Eng. 49, 815 (2015). DOI: $10.1134 / \mathrm{S} 0040579515060032$. 
2. Y. Zhang, A. Chen, P. Zhang, Y. Zhou, T. Zhang. WaterScience Technol. 77 (8), 77 (2018). DOI: 10.2166/wst.2018.121.

3. E. Torfs, M.C. Martí, F. Locatelli, S. Balemans, R. Bürger, S. Diehl, I. Nopens. Water Science And Technology 75 (3), 39 (2017). DOI: 10.2166/wst.2016.485.

4. H. Gao, M.K. Stenstrom. Water Res. 143, 445 (2018). DOI: 10.1016/j.watres.2018.06.067.

5. J. Yu, J. Fu. Sep. Sci. Technol. 55, 313 (2020). DOI: 10.1080/01496395.2019.1565772.

6. T. Han, H. Liu, H. Xiao, A. Chen, Q. Huang. Chem. Eng. Res. Des. 145, 12 (2019). DOI: 10.1002/cite.2019.00064.

7. X. Yang, M.J.H. Simmons, P. Liu, Y. Zhang, L. Jiang. Sep. Sci. Technol. 54, 2959 (2019). DOI: $10.1080 / 01496395.2018 .1548486$.

8. Sriyono, R. Kusmastuti, S.L. Butarbutar, D.H. Salimy, Febrianto, I.D. Irianto, M. Pancoko, G.R. Sunaryo. J. Phys. Conf. Ser., (2019). DOI: 10.1088/1742- 6596/1198/2/ 022040 .

9. M. Ghodrat, S.B. Kuang, L. Ji, A.B. Yu. Miner. Eng. 90, 55 (2016). DOI: 10.1016/j. mineng. 2016.03.017.

10. A.V. Busarev, A.S. Selyugin, N.S. Urmitova, F.F. Kayumov. Izv. KGASU 2 (36), 15 (2016).

11. A. Busarev, A. Selyugin, R. Abitov. Int. Conference «Scientific Res. SCO Countries» Sunergy And Integr. 166, (2019).

12. N. Urmitova, R. Abitov, A. Nizamova. IOP Conf. Ser. Mater. Sci. Eng. (2020). DOI: 10.1088/1757-899X/890/1/012151.

13. X. Wei, M. Kazemi, S. Zhang, F.A. Wolfe. Water Environ. Res. 92, 1695 (2020). DOI: $10.1002 /$ wer. 1424 .

14. M. Coha, G. Farinelli, A. Tiraferri, M. Minella, D. Vione. Chem. Eng. J. 414, (2021). DOI: $10.1016 /$ j.cej.2021.128668.

15. A.D.F. Ferreira, D.R.B. Coelho, R.V.G. dos Santos, K.S. Nascimento, F.A. Presciliano, F.P. da Silva, J.C. Campos, F.V. da Fonseca, C.P. Borges, S.E. Weschenfelder. Environ. Sci. Pollut. Res. 28, 12803 (2021). DOI: 10.1007/s11356-020-11265-2.

16. P.N. Egbuikwem, J.C. Mierzwa, D.P. Saroj. Bioresour. Technol. 318, (2020). DOI: 10.1016/j.biortech.2020.124200.

17. N. Makisha. IOP Conf. Ser. Earth Environ. Sci. (2020). DOI: 10.1088/1755-1315/459/4/042015.

18. O. Khalifa, F. Banat, C. Srinivasakannan, F. AlMarzooqi, S.W. Hasan. J. Clean. Prod. 289, (2021). DOI: 10.1016/j.jclepro.2020.125764.

19. E. Abdollahzadeh Sharghi, A. Shourgashti, B. Bonakdarpour. Bioprocess Biosyst. Eng. 43, 981 (2020). DOI: 10.1007/S00449-020-02294-9.

20. T. Kedrova, L. Khisameeva, R. Abitov. IOP Conf. Ser. Mater. Sci. Eng. (2020). DOI: 10.1088/1757-899X/890/1/012152.

21. V.V. Khaustov, V.V. Bredikhin, T.V. Khaustova, IOP Conf. Ser. Mater. Sci. Eng. (2019). DOI: $10.1088 / 1757-899 / 687 / 066063$.

22. L.A. Nikolaeva. Therm. Eng. 67, 751 (2020). DOI: 10.1134/s0040601520100080.

23. A.B. Adelshin, A.V. Busarev, A.S. Selyugin, L.R. Khisameeva. Izv. KGASU 2 (12), 57 (2009).

24. S. Oladzad, N. Fallah, B. Nasernejad. Water Sci. Technol. 76, 57 (2017). DOI: 10.2166/wst.2017.185.

25. T. Krahnstöver, A. Zenker, M. Baggenstos, B. Kobler, K. Leikam, G. Koch, T. Wintgens. Environ. Sci. Water Res. Technol. 5, 2172 (2019). DOI: 10.1039/c9ew00658c.

26. J. Lee, M. Lee. Water Sci. Technol. 79, 771 (2019). DOI: 10.2166/wst.2019.097.

27. S. Verma, A. Daverey, A. Sharma. Environ. Sci. Pollut. Res. 26, 34148 (2019). DOI: 10.1007/s11356-018-3551-4.

28. B.M. Gareev, A.V. Busarev, A.S. Selyugin, F.F. Kayumov. Collect. Sci. Pap. X Int. Sci. Conf. Eurasian Sci. Assoc., 48 (2015). 